\title{
The British Position towards European Integration: A Different Economic and Political Approach
}

\author{
David Ramiro Troitiño \\ Department of International Relations, \\ Tallinn University of Technology \\ Akadeemia tee 3 , \\ Tallinn 12618, Estonia \\ E-mail: perdices57@yahoo.es
}

\begin{abstract}
The United Kingdom has had an important position in Europe for centuries. Often it is seen as an anti-European country, or as being anti-integration in Europe but it is just defending its own interests, which in many cases have differed from other members of the European Communities. The UK policy towards European cooperation has been influenced by the particular interest of the country, but there has always been a strong relation between the British and Europe. Great Britain had the biggest empire in human history spread all over the globe, and hence its interest was global rather than limited to local European states. The UK was a victorious country in the Second World War, the only Western European state that participated actively in Nazi defeat. As an important consequence, British nationalism was seen as a positive force to unite all the British against an external threat. During centuries, the British economy has been based on trade, and internationally the government supported and expanded the free trade idea in the world economy to European trade relations. This paper analyzes the main issues that explain the special relations between the EU and the UK. The paper is developed from a historical point of view with a methodology based on the critical review of historical facts from a global perspective of the whole traditional approach of the UK towards European integration.
\end{abstract}

Keywords:British approach to Europe, British particularities in Europe, European Integration, European Union, UK-EU relations, United Kingdom 


\section{Introduction}

After the Second World War, the economic and social situation in Europe was severe because of the great destruction caused by the war. European states collaborated in order to rebuild their economies: the Marshall Plan, the Bank of Basel and other institutions were created or developed to increase cooperation between the countries of Western Europe. The communist bloc, directed by the Soviet Union, developed their own alternative cooperation through different plans and associations. The countries most affected by the postwar crisis were the European states that suffered in the war more significantly than countries in other parts of the world. Even the victorious contenders, such as the British, experienced difficulties in their postwar economies with several restrictions lasting several years after the conflict.

The post-war crisis in the United Kingdom had important consequences in international affairs as it changed the previous international establishment and a new world order was created. The country which was once the most important and powerful empire ever built by humanity lost its leading position in the world affairs to new world powers, the USA and the USSR. The transfer of power was a direct consequence of the Second World War because the conflict made the US and the Soviet Union stronger, and at the same time weakened the UK. It took time for the UK to adapt to the new international situation and understand the new world and the new role of the British in international affairs, mostly as a loyal ally of the US rather than an independent international political force acting exclusively according to British national interests.

Obviously there was a link between the national interests of the US and the UK because of the common values shared by both states, such as a political system based on democracy (even though USA is a republic and UK a monarchy), an economic system based on free market, on capitalism with some emphasis on the financial markets, or the language, and other cultural aspects that allowed a smooth transition from British dominance in world affairs to American leadership. These links are still strong and make the relation between the British and North Americans very close. Nevertheless there had been many occasions where the interest of both countries was not the same and hence the predominance of the US was shown in all its power forcing the British to readapt or reconduct its actions following the American interest. In the period after the Second World War, the best example was the crisis of the Suez Canal, in which French and British troops had to negotiate and withdraw from Egypt because of the American protection of Nasser as a key ally in the Cold War 
in the Arab countries. The special relation between the US and the UK also created tensions between the French and the British, as France felt betrayed by the British acceptance of American predominance. The independence of European colonies during the postwar years was also an expression of the same international situation in a world dominated by two new powers, the US and the Soviet Union, where the former colonial powers just step aside unable to compete with the huge resources of both states in the context of the Cold War between them. To give an example, Vietnam, previously a French colony, where France had fought a long war against the local independence, became a scenario of violent combats between capitalist forces lead by the USA and local Communists, armed and counseled by the Soviet Union. France was simply powerless to play in the same division because it could not match the capacities of the new world powers. The process of decolonization was the scenario of numerous conflicts between the USA and the USSR, where in the best of cases the European powers were assisting one of the contenders. Hence Europe was in a clear decline in international affairs, previously dominated by European powers for centuries.

\section{The main European interests to create a European organization after WWII}

Once the Second World War had ended, different European groups of interest were pushing for deeper collaboration in Western Europe as they saw a united Europe as the best way to solve the European problems. Eventually these economic, political and social movements led to the creation of the current European Union. The main reasons driving the process attended to the various necessities of Europe, mainly:

1. Europe as a peace system: A group of Europeans defended the idea that nationalism was the main cause of conflict on the European continent, the source of evil on the European level. The idea of superiority included in the concept of nation led to a confrontation between the European nations formed by European nation states. The problem was the use of the national spirit as the main vehicle of cohesion among the citizens of the European states because the nation transformed from something cultural, uniting people to the strongest political force of European politics but separating them according to nationality. The idea of Europe, understood as a peace system, wanted to avoid another conflict such as the First or 
the Second World War, and hence nationalism had to be kept fenced in the cultural sphere. If Europe could abolish the main obstacle to the common understanding, the unification of a cultural national group with a political state, Europe might then be integrated on the political level. At some point, political integration might lead to the state of Europe and thus wipe away any possibility of international conflict between the European nations. Europe was seen as a family of nations where citizenship should be separated from nationality.

2. Europe as a way of European states holding on to the international influence in world affairs: Some weakened powers of Europe thought of Europe as a solution for their loss of influence in the period after the war. Individually the European states did not have the resources and political muscle to interfere in world affairs independently, but uniting all these resources and using them for a single purpose would have restored the former European dominance in world politics, or at least would have equalized the power of the USA and the Soviet Union, keeping the independence of Western Europe and its international interest protected. Hence, Europe was seen as a necessity to defend European interests in the world.

3. Europe as a powerful economic tool: As the continent had been destroyed by the two devastating wars, there was a necessity to rebuild European economy. Europe followed the example of progresses made in the economies with large single markets, such as the USA. Increasing the size of the national markets to the European level was seen as an exceptional way to contribute to the economic recovery of Europe. Hence, removing economic obstacles to European trade would increase the number of economic transactions, thereby becoming an important contribution to the wealth of the European states.

4. Europe as a protection from the Soviet Union: The end of the Second World War meant the beginning of the Soviet occupation for many Eastern and Central European states. The Soviet expansion needed social instability to succeed in its international enlargement. Communism is a radical political system organizing the life of citizens from a radical point of view. The majority of the citizens of a society is conservative and dislikes social changes as long as the society meets their basic needs. The possibilities of a triumph of the communist alternative are much reduced in a peaceful society that can solve its internal problems without violence. On the other hand, acts of extremism become more popular during unstable times, when violence is more common, when the society is confused and cannot resolve its problems in a peaceful way. Then new ideas and changes are seen as a solution to the problems causing social unrest, a novel way to achieve 
social stability. Obviously the occupation of Eastern and Central Europe by the Soviet Union and the expansion of the communist system were a direct consequence of an armed conflict and an imposition of communist regimes by the powerful Red Army. This expansion, supported by the Soviet military forces, could not be applied to Western Europe because of the presence of American troops defending the area from any possible Soviet aggression and the creation of NATO, in which Western European countries collaborate in the defense field. Therefore, the national revolution was seen as the main threat to the expansion of communist regime all over Europe. In order to combat this internal threat, Western European countries thought of the European collaboration as a way to provide stability in their countries, increasing partnership and reducing the tensions between the countries. A peaceful collaboration between Western European countries would reduce the possibilities of social unrest, and a local communist victory, and the consequent dominance of the Soviet Union over the whole continent. Some Western European countries had important communist parties at that time, such as France or Italy, and the threat was very tangible. Other countries, such as Greece, could not keep the social peace and fought a civil war between communist and the most conservative political forces. The situation of internal social instability in Greece was resolved by a military regime by abolishing the political rights of the Greek people and bringing back, temporarily, stability by force. Europe then was a tool to create stability in the area to avoid a political and social crisis that could have led national communist parties to the national governments.

5. Europe as an international reconciliation tool: The countries defeated in the Second World War emerged as some kind of international political pariahs after the conflict. There was not much self-criticism on the winners' side, and the most common analyses simply pointed out the evil behavior of some European nations as the main reason for the war. The new confrontation between the USA and the USSR meant the necessity to recuperate these countries for the Western bloc and the blame for the war shifted from nations to its leaders, such as Hitler or Mussolini. West Germany became the border between East and West, the first battlefield in a possible AmericanSoviet confrontation on European soil. The creation of a powerful West Germany became a priority in stopping any Soviet aggression towards West Europe. Nevertheless, the restoration of German power was seen as a danger by many European countries because of the two world wars, so the best option was to include West Germany in a European Community where it could not act independently and attack any of its members. The idea was simple - what you share, you cannot use against the other owners. Also, 
West Germany saw this as an opportunity to show the rest of the Europeans its capacity to collaborate peacefully by following the rules created by all. Germany was internationally rehabilitated as it showed its capability of acting as a trustworthy partner in Europe and in the world. Also, it could be applied to other important Western European countries, such as Italy, though not to countries like Finland or Austria because of their neutrality status during the Cold War. The Soviet Union agreed to sign a peace treaty with the Finnish during the war on the condition that Finland becomes a neutral country, and agreed with the USA to withdraw the occupation troops from the Austrian soil under the condition of neutrality of the new state. The Soviets saw European cooperation as a weapon against the communist bloc and thus neutral countries could not join the European Communities until right after the collapse of the communist regime and the end of the Cold War.

6. Europe as an economic and social development tool: The dominance of some European countries over others and its leadership in world affairs was seen by some Europeans as a direct consequence of the economic power of these leading states. The UK, France and Germany were seen as the example to follow for the rest of Europe in order to develop economically and socially. The best way to catch up with the most developed economies of the continent was creating a community that could expand ideas, abolish customs, help for a faster economic development, and support economically the transformation of the less developed members. Europe was seen as a modernization opportunity and collaborating would spread the benefits to all of Europe. This idea also had a strong social component because it opened the collaboration to all the European states, poor and rich, as far as they fulfilled some basic requirements, such as a political democratic system and economic capitalism structure. Common rules helped to expand the benefits to the whole area, but the higher development in some parts meant a source of instability for the whole. Development aid was needed to avoid conflicts and increase the cohesion between the Western European states.

\section{The UK and its European interests after WWII}

The UK was a still the biggest empire on earth right after the Second World War, and a victorious country in the deadliest conflicts on the human history, the two world wars. The British had defeated Germany twice and with that their national spirit was reinforced. The UK had to stand alone in Western Europe against the 
powerful Nazis; it had been the only country able to oppose Hitler's designs, and this gave the British a feeling of exclusivity. The position and necessities of the British after the war did not precisely fit with the main aims of the forces driving to a United Europe:

1. Nationalism, British nationalism, was not seen in the UK as something negative, as something that had led the country to a confrontation with other nations. Nationalism was seen as a feeling that united the British people in their titanic effort against an external threat. The emotive speeches of Winston Churchill to the British people followed this pattern asking for a national sacrifice to defeat the Nazis. The British, united by the national feeling, could stand against any threat to their way of life. Obviously this was not a rational feeling, and this was not the right interpretation about what caused the Second World War, but was the feeling spread among the citizens of the UK. The British nation was seen as something benign in the fight supporting freedom and democracy against the totalitarian fascism. British nationalism was regarded as a model to expand to the rest of countries to erase totalitarian forces from Europe. So, the vision of Europe as a peace system to avoid conflicts generated by nationalism was not shared by the United Kingdom, and the idea to separate political power from the national level was seen as an attack to the British freedom, achieved in the war by the fight of the British nation against the German forces.

The UK as the only important country of Western Europe that was not defeated during the war, unlike France, Netherlands, Belgium, Luxembourg, Italy or Germany, had a significantly different approach to the matter, and the main British contribution to the debate of Europe as a peace system was following the same pattern than what was used before the Second World War - a community of free nations collaborating freely and in good faith with the partners. The idea was linked with a gentle conception about British nationalism and was hence extendable to other kinds of nationalism. The position of the British on nationalism was supported by two other nations not involved in the war, two national states not defeated, two states that had not suffered the severe conditions of the war-namely, Sweden and Ireland.

2. The United Kingdom was still the main world power in world affairs after the war. It was Churchill who organized the world affairs with Stalin and Roosevelt. The British used to believe that their country was still the greatest empire in the world history, but the time of the British as the world's hegemonic power was close to an end after the Second World War. There were some signs pointing to the direction of the end 
of the British Empire, but the long-passed triumph and a recent victory against the Axis forces made most of the British believe that their time was not still over and the British international power was still unmatched. Even the most capable politicians in the UK could not foresee the British decline: for example, Churchill believed in a new world order different from the past, with a balance between three powers - the USA, the USSR and the UK. The British politician, war hero and writer overrated the power of its country thinking it could still match the two new rising powers. The British decline from a leading position in world affairs to a middle power, still with important influence but no longer independent in its international agenda, was slow and in many cases smooth thanks to the tight collaboration between the UK and the USA. The predominant role of the UK in different parts of the world was taken for granted by the Americans as they shared the interests in many cases and the USA thus became the natural heir of British power.

Nevertheless, as the Yalta Conference showed, the UK did not have any need for Europe to keep their influence in the postwar world affairs, and thus the UK did not have any interest in participating in a European association to focus on this necessity. On the other hand, de Gaulle was trying to use the European Communities to implement a third way in the duality of the Cold War. Of course, the French president wanted this third way to be led by France and financed by Europe.

3. The third main idea about Europe was economic, expanding the European market in order to increase the economic activity and hence the economic performance of the weakened European economies. The war had meant a total focus on military priorities with a consequent shock for the production. The influence of the war on the people's life affected also the consumption and their own performance as economic agents. It was obvious that Europe needed a strong shock therapy to recover its sick economy. The ideas were multiple, from common rules to common trade. The UK was a fervent champion of the free trade in the European area as it had traditionally been in the world during centuries. Liberalism and trust in the market had the British footprints, going beyond the traditional democracy to a more free system based on the trust of the self-regulation of the economic agents. Milton Friedman's advocacy of free markets over government intervention and his prescription for fighting inflation by central banks were treated as fringe notions by many economists (Ip \& Whitehouse, 2006).

Since then the British have denied the necessity of a high regulation of the market, as it can regulate itself in a more efficient way, influencing 
the European and the world economy in this sense. Economic cooperation became a priority for the UK and the country became an important actor in most of the proposals launched in Europe in this field, but also developed its own world trade area, including the former colonies of its vast empire. Countries of world importance such as Canada, South Africa or Australia were included in the so-called Imperial Preference system inside a community of British ex-colonies, the Commonwealth. The idea of a Common European market was against the two main priorities of British economy at that time - the free trade and the development of the Commonwealth - because it meant the creation of an exclusive economic area close to its members that could not be enlarged to other parts of the world, the former British colonies. Also the Common European Market was to be regulated by the common institutions of the organization, against the idea of free trade and deregulation defended traditionally by the British government.

4. Europe as protection from the Soviet Union or Europe as a focus of stability was less important for the UK than for other European countries. British political system is, and was, one of the most stable democracies in the human history. Since the Glorious Revolution, the role of the British Parliament as a counterbalance to the monarchy created a constitutional system envied in the rest of the world; the own British people, conscious about their achievements, also felt proud of their political system. The stability of the system was so strong that during the Industrial Revolution, the growing British working class melted into the system without threatening to break it. The system was elastic enough to absorb the changes and incorporate the new necessities of the society to the traditional establishment without major shocks. The theoretical revolutionary Karl Marx predicted the triumph of the working-class revolution in the United Kingdom sooner than anywhere else in the world because the working class was more developed on the British soil than in any other country in the world. According to the communist perception of history based on linking stages of human development to production system, the society moves naturally to communism through a normal improvement of human relations. Obviously, Marx was wrong because communism has never been a tangible threat to the UK and it was mostly successful in more agrarian societies with a small industrial working class, such as Russia. As the political system was stable in the UK and the threat of an internal revolution leading to a communist regime was minimal, the country did not need to protect any European association. Also, the British institutions had shown during the war a great resistance against adversity and counted with a high 
respect from the British citizens, so there was either a necessity to back the political system or the state institutions with the popular legitimacy coming beyond the national borders.

5. Europe as a way to restore the international role of the country was not a necessity to the UK as it kept its prestige intact in the period after the war. The British had suffered a long war but were still controlling the biggest empire in the world history. The UK was still the leader of the free world in Europe, the leader of democratic systems against totalitarianism, but in the postwar period the domination of the international relations of the two new world powers, the USA and the USSR changed the international scenario. The British government had alternatives to reverse its growing international weakness and opted to follow with its traditional policy of deep collaboration with the USA. The Americans had helped the British twice to defeat its European enemies. The First World War was on standby after many years of bloody conflict; the German Empire had already succeeded on the Eastern front and could then focus on the French front, strengthening its position. The US joining the war on the British side broke the balance and ended in a victory to the Allies. The subsequent Americans' withdrawal from the world politics kept the British status in world affairs intact. The Second World War was clearly on German side with the fast conquest of France and other Western European states. On the East front, the Germans were fighting on the Soviet soil, with Eastern and Central Europe under its power. The United Kingdom was completed isolated in Europe, as it was the only important country able to resist the Nazis. The rest of Europe was occupied by Germany, or allied with Germans or in a delicate neutral position. The USA again became the UK's savior, but this time American contribution to the war was more important, as there was no balance of power in Europe as it had been in the First World War, but only German hegemony. The Soviet Union and the United Kingdom survived owing to the technological and material support of the Americans and its enormous market economy, and once the US joined the conflict, the Germans' defeat was decided. The US had saved the British twice from the German threat. The USA also shared cultural similarities with the UK and their way to understand economy and politics were similar. So, the most obvious decision for the British government in the international arena was to work closely with the USA. It allowed a smooth transition in the world, as the previous world power, the UK, agreed to collaborate with the new one, the USA, without major conflicts between them. It allowed the Americans to use British expertise and British allies to increase its power, and permitted the British to keep some influence in world affairs 
that otherwise would have been lost, as it had happened before with other hegemonic world powers. Nevertheless, the decision of the British to work closely with the USA was more sensitive than collaborating with former British enemies to build an uncertain community of common interest.

\section{Winston Churchill and European Integration}

Winston Churchill (1874-1965) made an important speech about European integration in Zurich (on 19 September 1946). This outstanding politician, popular writer and war hero proposed an organization where France and Germany could cooperate and avoid the possibility of a new war between them. Churchill's main concern was a new conflict that could force the UK to participate in another world conflict. He was a politician born during the peak of the British Empire and still thought of the UK as a great power in the world, so the involvement of the British in this European organization was limited to being a friend and a supporter, but never a full member. He thought of four world powers - the USA, the Soviet Union, the UK and the future European Federation. According to Churchill, the organization had to be open to all the non-communist European states, based on democratic principles with a federal nature. The involvement of Germany and France was to be decisive and the center of the organization because the main objective was ensuring peace between France and Germany and all their allies. The working system of the organization was meant to be based on federalist principles. (Churchill, 1946)

Churchill's famous speech had a great influence on the further development of the European Union, or as he called it, the United States of Europe. The British leader spoke about the necessity of integrating Europe in order to avoid future wars. According to his words, the center of the community must be France and Germany, two states which have had many conflicts in the past and which have led twice to a global confrontation in which the rest of the states, and specially the UK, were involved. Churchill supported integration, and saw it as a requisite for world peace. He thought of the UK as a promoter of the integration of continental Europe, as a father guiding France and Germany during the process, but never as an active partner in the integration. He thought of the USA, the Soviet Union and the UK as the world powers ruling the world. The great British premier, who many times before had been able to analyze the international situation with amazing exactitude, completely missed at that time the British reality and the British position in the new world after the Second World War. 
British contribution to the Congress of Europe was following a similar approach. The Congress was divided in three main groups: the supporters of the European Federation, the supporters of Cooperation, and the supporters of Pan Europe, Britain being the leader of the so called Unionists, or supporters of cooperation. Their attitude towards the process was mainly positive, but underlining the importance of national sovereignty and trade.

\section{The United Kingdom and the first European Community}

Step by step the UK faced its decline and saw the end of the British Empire with the independence of most of its colonies and its decreasing role in the international arena where it could not compete with the USA or the Soviet Union, because it lacked the economic and material means to stand equally with the new giants. At the same time, British economy was in an important recession, losing positions with other European economies that were growing faster than the British. The previous British predominance over the world and over Europe was ending, and a new scenario arose. The United Kingdom was still an important country in world politics but the leadership of the Western bloc was under the Americans.

The first European Community was the European Coal and Steel Community (ECSC), an important economic sector in British industry, so the British government was interested in participating in the new community as a way to fund the deficit of the sector and gain for British producers access to German and French markets. It was an economic sector under crisis, but it also had a strong power in British politics through trade unions. The UK sent some delegates to discuss the inclusion of the UK in the still not created ECSC, but withdrew when the principle of national sovereignty was not respected, pointing out their interest in the trade area and political cooperation, but not in integration. For the same practical reasons, the British were in conversations leading to the foundation of the European Economic Community with the Treaty of Rome, but again, as previously, they did not take part in the new community and withdrew from the final talks.

The situation was difficult for the British because their economic performance was not as good as in other parts of Europe. It was because their European partners were successful as a consequence of the Treaty of Rome and the creation of the European Common Market. As the economies of the member states integrated in an interior market with common borders, the UK was left outside, 
as an external partner, losing access to an important market for them, even more important after the end of the British Empire and with American predominance in the world economy. So they tried to create a parallel community in order to gain access to new markets and end the exclusion of the British from Europe.

\section{European Free Trade Association}

The European Free Trade Association (EFTA) was the British alternative to the European Communities. It was established in 1959 with signing the Treaty of Stockholm by some European states, and the organization expanded further to include the UK, Austria, Denmark, Norway, Portugal, Sweden, and Switzerland among others. The other states had different reasons for joining this new European organization-Denmark and Norway had important economic links with the UK, and thus needed to be in the same organization as the UK in order to have access to the British market. Austria, Switzerland, and Sweden had the status of neutrality in the Cold War, and could not join the European Communities because it was seen by communists as an organization against the workers of the world supported by the USA and hence against the Soviet Union. Joining the organization meant joining one side of the Cold War against the other. On the other hand, Portugal was not a democratic country as it was under the power of dictatorship built by Salazar, and a democratic system was a requirement for joining the European Communities; Portugal could not join it. The EFTA gave international backing to the Portuguese regime plus the important economic ties the country had with the UK.

The new organization proposed a different model for uniting Europe, one mainly based on trade and common agreements, without integration or any loss of national independence, following the ideas formerly expressed by the UK. The working system was based on the good faith of the partners and their will to collaborate with each other, reaching common positions based on consensus. In practical matters it was an organization based on industrial production trade, excluding agricultural products, an area of free trade based on the British tradition without any political meaning.

The organization initially worked, and more countries joined the organization, and Europe was divided in two main markets, two main economic areas. But the member states of the European Communities were performing economically better, growing faster and increasing their economic role in Europe. At the same time, British economy had many problems and the market of the EFTA was 
not big enough for its economy to solve its problems. As the UK was being left behind France and Germany, and its economy was in crisis, their government had no choice other than asking for membership in the European Communities, even when this decision was against their political beliefs based on cooperation and free trade. In practical matters it meant the end of the EFTA, because its main partner was going to join the European Communities, and hence the EEC market, with common borders against any other external country or economic area. The free trade area had no chance to grow without access to the British market, and Ireland, Norway, and Denmark asked at the same time as the UK for membership in the European Communities. Once they joined, the stature of the EFTA decreased and became a mere annex to the EEC market.

\section{UK's first and second petitions for membership}

The British encountered many problems in joining European Integration because they were seen as close allies of the USA. It provoked fears in the other members of the EEC because they wanted to keep some independence from the USA, especially France. The decision of the USA, backed by the UK, in accepting the division of Germany into two parts, alienated the British from West Germany. It meant the hidden support of Germany in favor of the negative position of the French towards the UK in this matter. On the other hand, other member states were interested in the UK's being inside the Community, because they, especially the Netherlands, had important economic links with the British, but their influence could not stand up to the French rejection. Other supporters of British membership were important figures linked to European integration, such as Jean Monnet, the so-called "Father of Europe", but they could do nothing against the combination of French and German positions.

France had many reasons for rejecting the British application, first of all the leading position of France inside the Communities as its main political actor. The Second World War was still recent and Germany was willing to cooperate with international partners as a way to show their good faith. The inclusion of West Germany in the European Communities was a big step in rehabilitating this state in the international arena. The other member states, such as the Benelux countries and Italy, did not have the power to challenge the French position. So France was the leading political force of the Communities, a position that could be in danger with another heavyweight partner, such as the UK, inside the Community. 
On the other hand, British economy had important ties with the Commonwealth, an organization that included many former British colonies (see Fig. 1). It was not compatible with the European market because of the system of Imperial Preference on trade within the Commonwealth that gave practically free access to the British market to products of the members of the British Commonwealth.

The accession of UK to the European Communities included the British economy inside the European market; the imperial free access would have expanded to the whole European market because there were no internal borders. So this system needed to be changed against the will of the British, who still hoped to keep some influence in world politics via their Commonwealth. This problem also had an influence on the relations of the Communities with its former colonies via the Lomé agreements; of all the members of the European Communities, only France had ex-colonies of importance. France was using these agreements to keep its influence over these territories, and including the numerous British ex-colonies in the Lomé agreement could mean the end of French influence.

Figure 1. The British Empire in the 1920s.

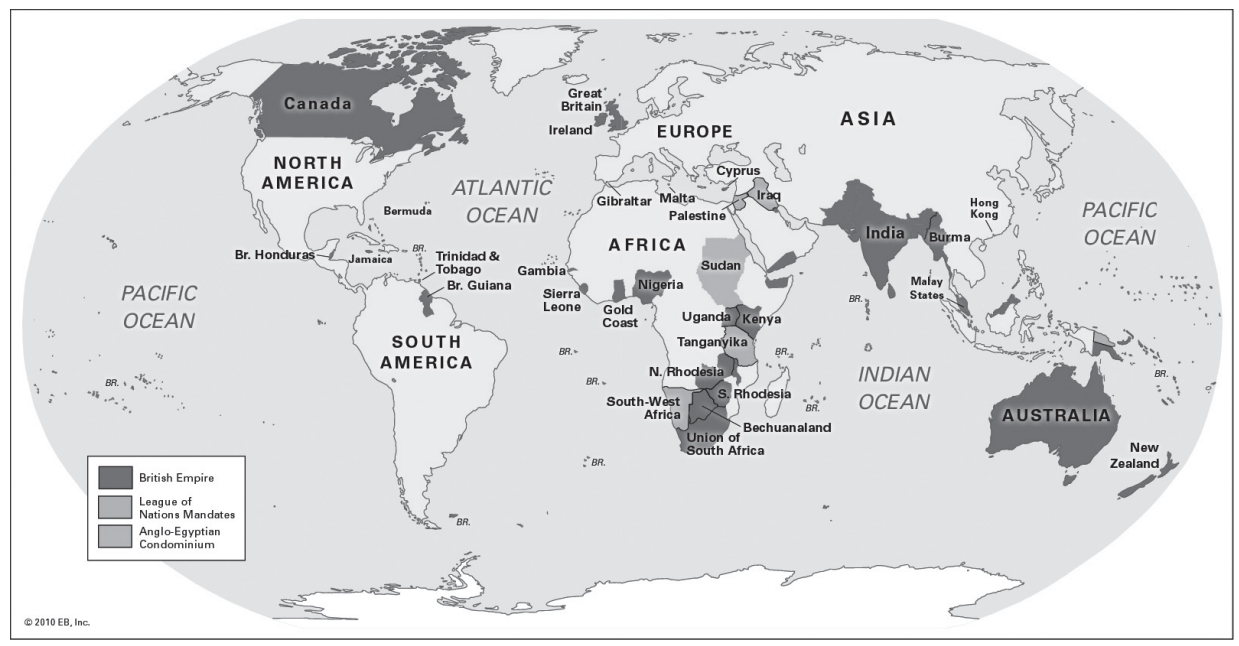

Source: Encyclopedia Britannica, 2010

Finally, the Common Agricultural Policy (CAP) was still under discussion, without its final shape, and the French government was concerned with the UK changing the rules of this policy because the British agricultural sector was very different from that of France and had other needs. Even today, the idea is still clear that when a country joins the European Union it has to accept the whole of it, it cannot join some parts of the Union and leave aside others. Once the 
country is a member, it has two possibilities to influence the development of European policies on the common ground of the European institutions-reject new policies unless they fit the country's wishes, or sign a special protocol that leaves the given country outside this new policy. As France needed the CAP because of internal reasons, they could not accept British membership until this policy was approved by the Communities.

As is the case in any enlargement, even today all member countries need to arrive at agreements, hence unanimity is required, which in reality means that each member state has the right of veto; Charles de Gaulle rejected the application of the UK twice because it was opposed to French interests. Therefore, neither Denmark, Ireland nor Norway, which had applied commonly with the UK, were accepted into the Communities. Eventually, the third application was accepted when Pompidou was president of France after the retirement of de Gaulle and the final approval for the CAP.

\section{Conclusions}

The British after the Second World War did not have the same necessities as most of the continental Europe; its internal and external situations were different, and thus there was no other reason for the UK to promote European integration. The United Kingdom became a friendly external sponsor to the peaceful cohabitation between the European powers in order to prevent another conflict affecting the country's stability.

The British necessities had changed from the period right after the Second World War until the enlargement because of economic and political reasons. The country no longer enjoyed a leading position in world affairs because of its incapacity to compete politically, culturally or economically with the USA and the USSR; also, its economy was in clear decline. The solution for its problems was to be found in the European Communities with a big market and the collaboration of the member states in the international arena.

The British had asked for membership under a Conservative government, but also under a government lead by the Labour Party. So it is obvious that there was common agreement between the main political parties of the UK about the necessity of joining the European Communities. For the UK, the enlargement also meant the inclusion of Ireland and Denmark in the European Communities, and the application of Norway was also accepted, but a domestic referendum in 
the Scandinavian country had a negative result for the European aspirations of its government.

Nevertheless, the British were aware of the meaning of the European Communities; the Schuman Declaration was a public document, the concept of shared sovereignty was included in all the treaties of the Communities and British officials were aware that the European communities had the political long-term goal of uniting its members in a single political structure. The decision of the British was a matter of priorities, economic development and international influence and political power were more important than British sovereignty. Therefore, it cannot be said that the British simply joined a Union of trade and with the current political development of the European Union, its essence has changed and the UK should withdraw from it.

David Ramiro Troitiño, PhD in European Union studies from the University of Salamanca, Spain in 2005. He has pursued his academic career mostly in Estonia, at the universities of Tartu, Concordia, Audentes and the Tallinn University of Technology, where he has been teaching different courses that mainly focus on the European Union issues. The author has taken active part in different conferences around the world related to the European Union in places such as Latvia, Turkey, Romania, Spain, Russia, Malaysia, Cyprus, Macedonia, and Colombia. Ramiro has published 30 international articles related to the European Union and his recent publications include European Integration: Building Europe (New York: Nova Science Publishers, 2013).

\section{Bibliography}

Bartlett, C. J. (1989), British Foreign Policy in the Twentieth Century (British History in Perspective), London: Palgrave Macmillan.

Black, S. W., ed. (2008), Europe's Economy Looks East: Implications for Germany and the European Union, New York: Cambridge University Press.

British History Online (n.d.) [Database], Yale University. Retrieved from http://guides. library.yale.edu/20thcenturybritish [accessed Apr 2014]

Churchill, W. (1946), Speech delivered at the University of Zurich, 19 September 1946. Retrieved from http://www.ena.lu/the_zurich_speech-020100043.html [accessed Apr 2014]

Costa-Font, J. (2012), Europe and the Mediterranean Economy, Routledge Studies in the European Economy, Abingdon: Routledge. 
Crafts, N. (2008), 'Want faster European growth? Learn to love creative destruction,' VoxEU, 11 July 2008.

Encyclopedia Britannica (2010), 'Ango-Egyptian Condominium: The Commonwealth,' [Image] Britannica Online for Kids. Retrieved from http://kids.britannica.com/ comptons/art-143476 [accessed Apr 2014]

Follesdal, A. \& Koslowski P., eds. (2010), Democracy and the European Union: Ethical Economy, New York: Springer.

Glenn, J. C. \& Gordon, T. J. (2007), 2007 State of the Future: Status and future global challenges, The Millennium Project, Washington, DC: World Federation of UN Associations.

Gnesotto, N. \& Grevi, G. eds. (2006), The New Global Puzzle, What for the EU in 2025? Paris: European Union Institute for Security Studies.

Imperial College London (n.d.), Homepage. Retrieved from http://www3.imperial. ac.uk/ [accessed Apr 2014]

Ip, G. \& Whitehouse, M. (2006), 'How Milton Friedman Changed Economics, Policy and Markets,' The Wall Street Journal Online, 17 Nov 2006. Retrieved from http:// online.wsj.com/article/SB116369744597625238.html [accessed Apr 2014]

McKay, D. (1999), Federalism and European Union: A Political Economy Perspective, Oxford \& New York: Oxford University Press.

Neal, L. \& Barbezat, D. (1998), The Economics of the European Union and the Economies of Europe, Oxford \& New York: Oxford University Press.

Pisani-Ferry, J. (2005), 'Speeding up European Reform: A Master Plan for the Lisbon Process,' CESifo Forum, vol. 6, no. 2, pp. 21-30.

Roger, L. (1999), The Oxford History of the British Empire, Volume IV: The Twentieth Century, Oxford: Oxford University Press.

Twentieth Century British History (n.d.), Journal homepage. Retrieved from http://tcbh. oxfordjournals.org/ [accessed Apr 2014] 